\title{
INTENSIFICATON OF KNOWLEDGE MANAGEMENT SYSTEM WITHIN THE FRAMEWORK OF ADULT LEARNING FOR EFFECTIVE REGIONAL DEVELOPMENT
}

\author{
INESSA VORONTCHUK ${ }^{1}$, IRINA LANDO ${ }^{2}$ \\ University of Latvia (Latvia)
}

\begin{abstract}
The article analyzes the possibilities of use of innovative methods of instruction for adult learning in the regions with the purpose to intensify the knowledge management system and ensure the principle of equal opportunity for the inhabitants of the regions. The data were acquired in the course of implementation of the national programme Support for Vocational Education with the Aim to Develop Professional Skills and Competences of People Involved in Agriculture and Forestry within the project Vocational Education 2005-2006. The project was being implemented in the time period from 2006 to 2008 inclusive. In the course of project implementation, trainings in 21 regions of the Republic of Latvia had been carried out. All in all, 2,562 people in 119 groups had been trained.

KEY WORDS: adult learning, knowledge management, regional development.
\end{abstract}

JEL CODES: H250, O110.

\section{Introduction}

The modern knowledge-based economy established the human capital as the key factor for the successful development and increased competitiveness not only for the organizations, but also for countries. For example, the Latvia's Sustainable Development Strategy 2030 states that "Our main capital is people - their skills, knowledge and talents". Development of adults through training can reduce the gaps in knowledge distribution and speed of knowledge delivery between regions and cities.

Development of regions is one of the key priorities of the republic of Latvia. Thus, development of human capital in regions requires introduction of innovative training approaches targeted at processing newly acquired knowledge.

During the past decades, considerable changes occurred in the sphere of the adult training. These changes are mostly caused by a few new tendencies: globalization, migration, creation of the common European labour market, consequences of the global economic crisis, ageing of the nations in Europe. During an informal meeting among the heads of the EU member states in Hampton Court (UK) in October 2005 it has been noted that ageing of the nations has become one of the major problems that should be resolved in the nearest future. The negative demographic tendencies related to ageing of population and, consequently, to the labour market, will inevitably affect quality of workers and will require more robust trainings aimed at

I Inessa Vorontchuk - Prof. dr. oec., University of Latvia, Faculty of Economics and Management. Scientific interest: public administration.

E-mail: Inessa.Vorontchuk@lu.lv

Tel.: +371 67034740 .

2 Irina Lando - the University of Latvia, Faculty of Economics and Management. The applicant for scientific degree. Scientific interest: Innovative training methods for personnel, speed reading.

E-mail: info@lando.lv

Tel.: +37129433553. 
improvement of the professional abilities and skills, as well as professional qualifications which are widely available in the cities, but not the regions.

As a result, new approaches and tendencies are required for educational activities conducted in the regions. These new approaches should be focused on improvement of professional qualifications in line with the concept of lifelong learning.

The EU member states have established state policies identifying knowledge as a basis of development in the society and highlighting importance of the concept of lifelong learning. The lifelong learning concept reflects the potential and key tasks of the informal training approaches. These are the informal training approaches that actively use new forms and methods of training. Mostly, these are numerous methods of active trainings.

The object of the research is training and development of adults in the regions.

The paper aims to determine and evaluate the possibilities of intensification of the knowledge management system using adult training in Latvia for regional development.

The objectives set for the research are:

- To investigate characteristic features of the knowledge management system in the regions;

- To investigate the possibilities for intensification of knowledge management through training and development of adults.

The research methods applied are: scientific literature analysis, an experiment carried out with the aim to provide trainings to adults in the regions, the data collected in the course of training that were then statistically processed.

After trainings in each group, the trainees filled out questionnaires to evaluate the results obtained in the course of such instruction as well as to express their points of view on the organization of said trainings and the topicality of the themes covered and also assessed the possibility to apply the acquired knowledge in practice. The obtained data were then collected and analyzed after which the comparison of the results of trainings across regions was conducted, and, finally, common features were revealed and differences determined. In this article, the results are given in abridged form, since special features of development of 21 regions are of interest only to the domestic market taking into account the small area of Latvia. In this article, the authors present the general results which may be of interest to the wider public and can be used for the assessment of regional development.

\section{Research Topicality}

In the European Union, increasingly more attention is given to regional development. From the point of view of the authors, it is necessary to pay more attention to the specific nature of regional development in each individual country taking into account cultural and national peculiarities. For instance, people living in the old EU countries would find it difficult to imagine that in the new member states of the European Union there are regions in which the Internet is not available, that there are regions in which people do not have rudimentary knowledge of how to learn, search for and work with information. In fact, information becomes knowledge only after it has been processed by a person.

Growth and emergence of new technologies requires steady development of new competences in people, since any strategic development which assigns an independent part even to the most contemporary technologies will be doomed to failure if labour potential development is not taken into consideration (Lundvall and Tomlinson, 2001).

In this day and age, it is worth considering not only human capital, but also social capital as an integral part thereof (Corredoira and Rosenkopf, 2010), since an important part of knowledge exists in the connections between people (Blackler, 1995).

Flexible thinking, the rate of adaptation to new conditions and flexibility, i.e. skills which can help with the transfer of knowledge from one context to another, become even more popular (Argote and Ingram, 
2000). In the regions, people are known to hold quite conservative points of view, and the degree to which people are prepared to change limits the introduction of innovations and changes (Fisher and Torbert, 2000). Today, people must learn faster than the environment changes and should constantly search for new fields of study (Joy-Matthews and others, 2004).

People must know how to be oriented in the information flow and introduce innovative changes into behavior facilitating steady spread of knowledge. The question of increase in the capacity of acquisition of new knowledge becomes topical (Uhlaner and others, 2007).

\section{Description of the issue}

As noted in the EU 2020 - the Lisbon Council report, it is necessary to define skills that adults should possess to increase their competitiveness. The core skills are those that can be demanded for a long period of time and abilities of analytical thinking, not the routine work skills (Hofheinz, 2009).

The European Commission has been actively involved in the development of the Smart Growth concept in order to increase employees' motivation towards acquiring new skills and improvement of professional abilities. The European Commission has also been developing the Inclusive Growth strategy aimed to increase the number of efficient and trained employees that will ensure economic, social and territorial development and growth.

In Latvia, the program of training of adult people with objective of increase in the competitiveness of adult people in regions has been completed in 2006-2008. The program was developed and put into practice within the scope of the "Vocational Education 2005-2006" project. In total, over 2,562 people in 119 groups in 21 regions of Latvia have been trained within the scope of this program.

All project materials gave been recorded and made available to government bodies and the bodies of the European Union within the Lifelong Learning program.

\section{Novelty}

During implementation of this project, the approach was used for the first time which, instead of conforming to the project regulations, attempted to make this project actually useful for those who complete training. In this case, trainers were selected with great care and considerable attention was paid to preparation of materials.

Such approach allowed building a good reputation of the facilitator and, as a result, at the end of project implementation strong relationships with the regions were established.

The European Union implements excellent initiatives in the sphere of regional development. But at places these initiatives are often given a cautious welcome. The basic obstacles are alerted attitude to external trainers, lack of skills necessary for learning, incomprehension of the need to learn and develop, and inability to apply the acquired skills in practice.

In the course of implementation of this project, the attempts to eliminate these non-conformities and obstacles by means of intensification of the knowledge management system were undertaken.

\section{Results}

For implementation of the national programme Support for Vocational Education with the Aim to Develop Professional Skills and Competences of People Involved in Agriculture and Forestry, the project Vocational Education 2005-2006 was implemented. In the course of project implementation, the availability of on-site trainings and uniform distribution of the training programmes on the territory of the Republic of Latvia was a must in order to ensure the principle of equal opportunities for people from different regions, which facilitated the reduction in the differences in information accessibility for people from the regions in comparison with people from the cities. For implementation of the project, groups were formed on a vo- 
luntary basis in 21 regions of Latvia. Groups were formed under the principle of openness and accessibility to all comers. For this purpose, the opportunity to pass free education was advertised in local newspapers, on the Internet portals and in rural service centres. At the initial stage of project implementation one of the authors of this article - Irina Lando - personally organized and conducted trainings on Project Management, Company Management, and Contemporary Ways of Working with Information. In the course of instruction of first groups, corrections were made to the processes of instruction.

In the course of project implementation training modules were used for the instruction of adults. After trainings in each group, questionnaire of all the adults who completed training was conducted as well as a random sample of people who participated in trainings were surveyed.

It is important to note that during implementation of the project there was a prerequisite that in each group the quantity of women who completed training would be not less than $50 \%$. Since the project was co-financed by the EU funds, the principle of equal opportunity for the least protected population strata was thus ensured.

In trainings conducted in the regions insufficiently qualified trainers are quite often involved. Therefore, people in the regions do not trust trainings conducted by external trainers. In the course of project implementation, considerable attention was paid to the qualification of trainers and preparation of handouts so that the skills acquired in the course of training could be reinforced and repeated after the end of training (see Table 1).

The majority of the trainees assessed the quality of training as high (see Figure 1). It made organizing further on-site training possible. Since people in the regions unwillingly attend even free trainings, maintaining a reputation which guarantees the quality of training is essential to make implementation of long-term projects in the regions possible.

As a rule, people living in the regions quite often make a decision to start learning based on the opinions and recommendations of their acquaintances or neighbours.

Table 1. Project Assessment "Vocational education 2005-2006"

\begin{tabular}{|l|l|l|}
\hline \multicolumn{1}{|c|}{ Assessment Criteria } & $\begin{array}{c}\text { Number of trainees answered } \\
\text { 'good" or “very good" }\end{array}$ & $\begin{array}{c}\text { \% out of the total number of } \\
\text { trainees }\end{array}$ \\
\hline Overall training assessment & 2353 & 92 \\
\hline Facilitator's assessment & & \\
\hline Ability to explain complex concepts / tasks & 2341 & 91 \\
\hline Use of practical examples & 2117 & 85 \\
\hline Work with trainees & 2098 & 82 \\
\hline Training Materials & & \\
\hline Content & 2128 & 83 \\
\hline Quality of Handouts & 2094 & 82 \\
\hline Practical Use of Handouts & 2345 & 92 \\
\hline Learning Environment & 2315 & 90 \\
\hline Key “A-Ha!" Moments & & \\
\hline New knowledge and skills & 2472 & 97 \\
\hline Training materials can be used for self-study & 1896 & 74 \\
\hline
\end{tabular}

Source: authors research, $2008, \mathrm{n}=2562$

For implementation of the Bologna process, the quality of teaching must ensure interest in the process of learning. In this context, the trainer must not only act as an expert, but should also know how to flexibly react to the need of the audience. 


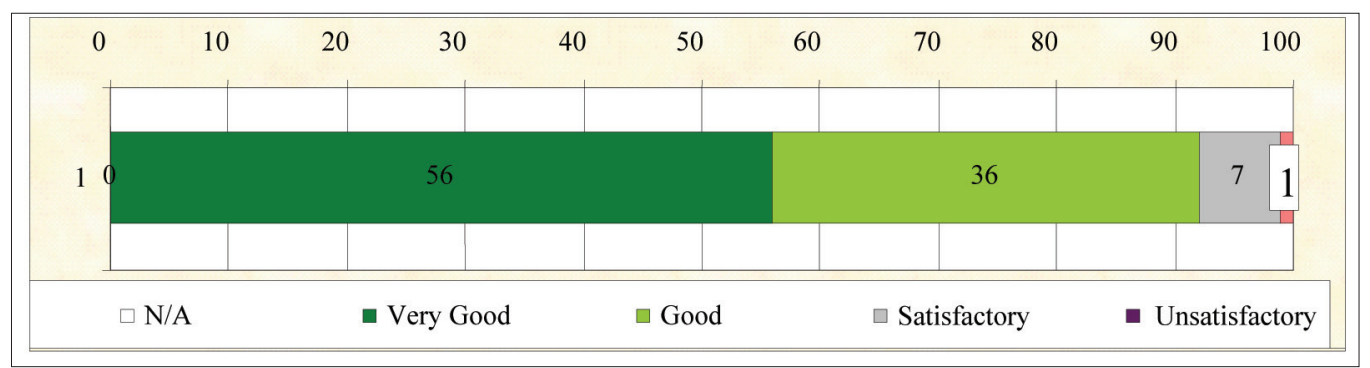

Figure 1. Overall Training Assessment

Source: authors research, 2008, n $=2562$

One and the same theme had to be explained differently in different regions using the examples which corresponded to the local specifics. Judging by the opinions, this principle was successfully applied (see Figure 2).

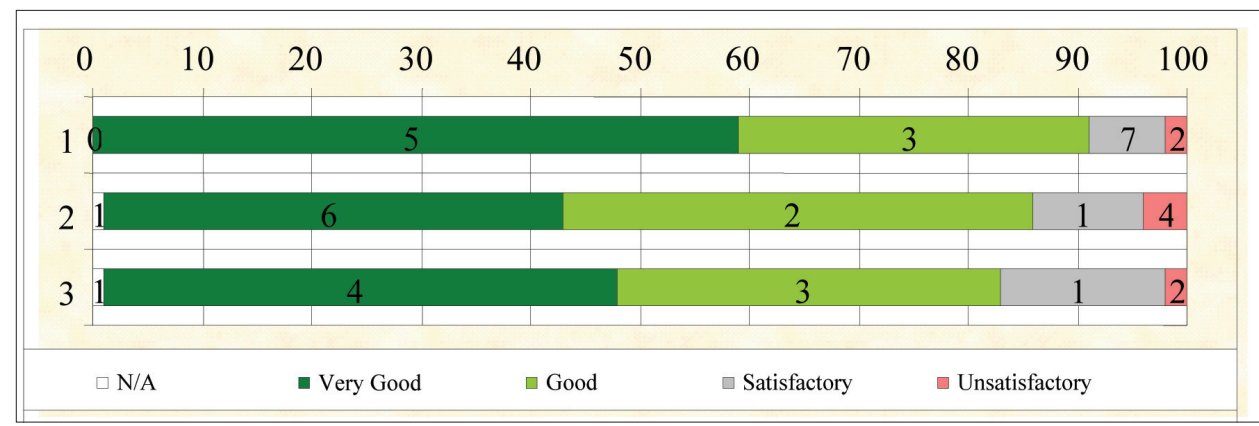

Figure 2. Facilitator's Assessment

Source: authors research, $2008, \mathrm{n}=2562$

The most complicated in this context is adhering to the programme described in the project. The project has a clear structure and the trainer must follow it; at the same time, people in the regions are simple and open-hearted and if they find a theme unnecessary, they will simply not learn it.

The project strictly regulated the requirements for the handouts, the design and information content thereof. It was important for the trainees in the regions that after trainings they could keep the materials using which they can repeat the material covered during their training. Material preparation involved solving a number of tasks which seemed mutually excluding. On the one hand, all the materials had to be brief and informative, and, on the other hand, people in the regions often do not have the faintest idea of the disciplines which others may find elementary. To ensure that the entire group could use identical terminology and employ the same definitions, it was necessary to prepare additional materials that were not paid for by the project.

At the places where trainings were conducted, trainees often complained about rather formal approach to teaching in the regions, that the trainers from the cities did not understand the specifics of work in the rural area and thus were telling about some book-learned things.

In the course of project implementation this problem was successfully solved by means of the knowledge management system which made it possible to react to the specific character of training in each group as quick as possible. If in the course of the first hour of instruction it was apparent that the trainees needed an easier mode of delivery of the material, the trainer during the first break informed the project manager of it and the latter made sure that all the necessary changes were made and on the next day the trainees could get the materials meeting their demands (see Figure 3). 


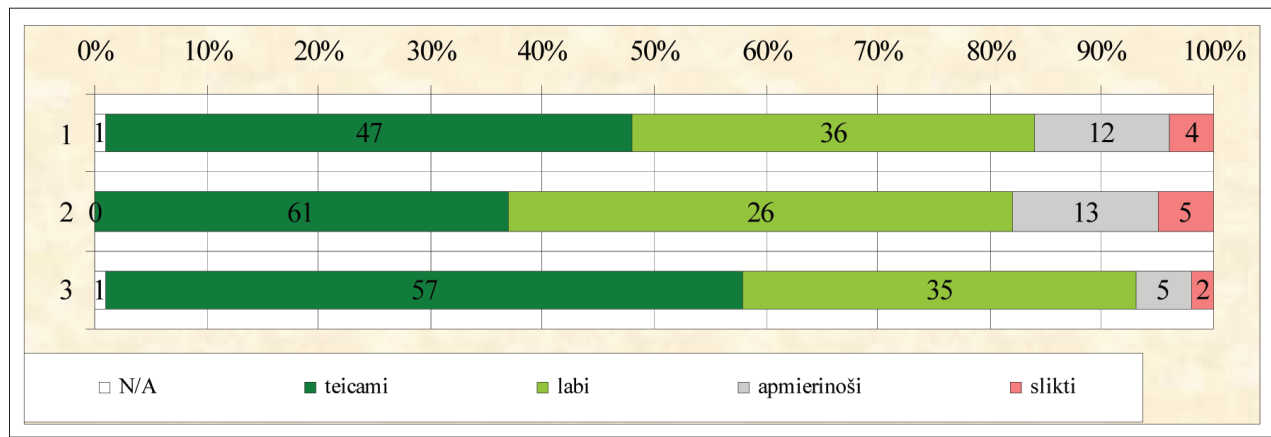

1 - Content; 2 - Quality of Handouts; 3 - Practical Use of Handouts

Figure 3. Assessment of Training Materials

Source: authors research, 2008, $\mathrm{n}=2562$

Instruction in the regions strongly differs from instruction in the capital. For many people it is not only an opportunity to acquire new knowledge, but also a possibility to meet their acquaintances, to socialize; for many people it is a real holiday. Therefore, considerable attention should be paid to the Learning Environment (see Figure 4). Creation of a specific environment contributes to the process of knowledge transmission and can help in the intensification of this process and make it more effective.

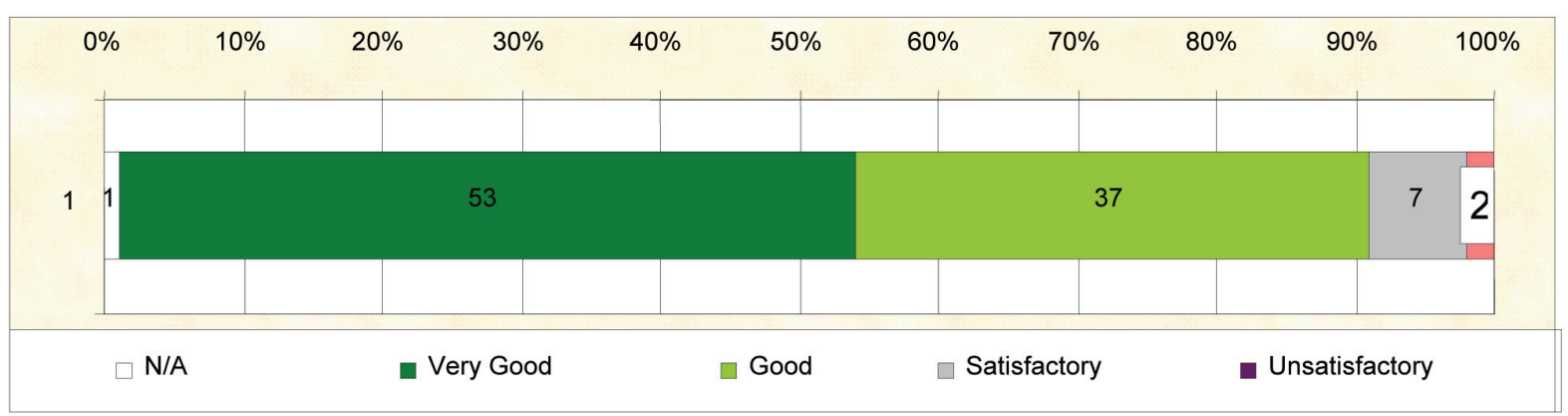

Figure 4. Learning Environment

Source: authors research, $2008, \mathrm{n}=2562$

Organizing trainings in the regions, not only the disciplines stated in the project should be explained to people, but also the need for the very process of learning and self-development should be emphasized. People who do not know what they do not know will not search for the information about the existence of which they simply do not know. It widens the gap between the regions and the centre (see Figure 5). Therefore, it is important that a trainer is also an inspirer for those who learn. 


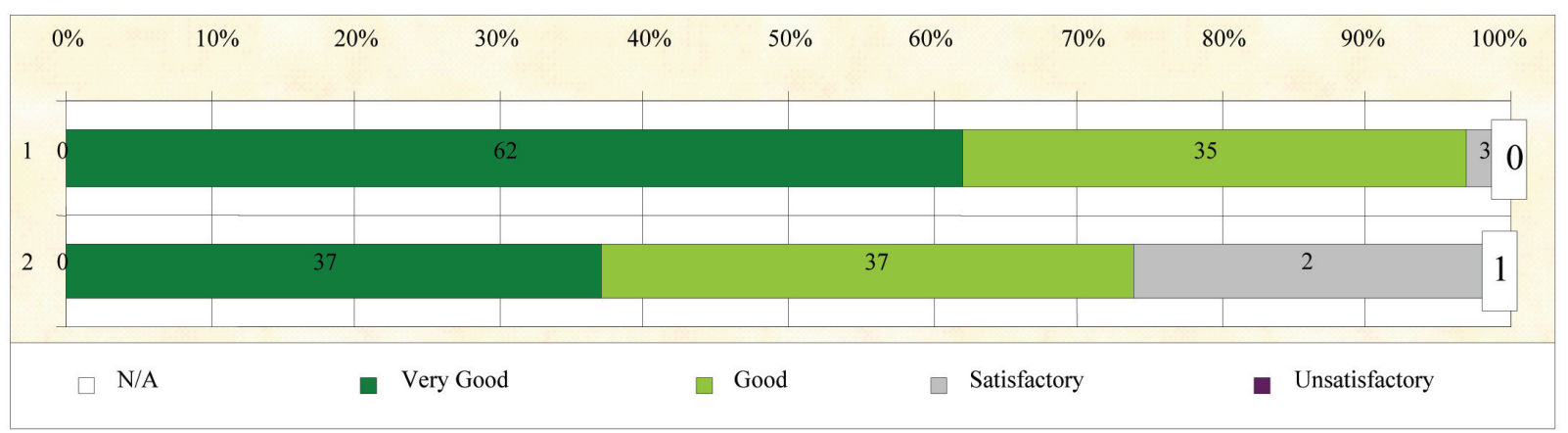

Figure 5. Key “A-ha!” Moments

Source: authors research, $2008, \mathrm{n}=2562$

Instruction in the regions requires the trainers to be more flexible, since they are the representatives of the facilitating organization and people associate such training with the EU funds which ensure its on-site implementation.

At the end of trainings, questioning of every adult who completed the instruction was conducted. In addition, expert surveys about the quality of instruction were conducted every day of trainings and necessary changes in the process of instruction were introduced on the basis of feedback. Sometimes it caused difficulties, since all the projects co-financed by the EU funds have a very rigid formal structure and it was complicated for the facilitators to introduce changes in the already adopted procedures of instruction. On the other hand, it is worthwhile to remember that working with people implies commitment to the result, i.e. the opinion of the trainees must be taken into account. Besides, the project aims at giving the trainees the knowledge which they can then apply in their work.

\section{Discussion}

According to the Pan-European Strategy 2020 and the Bologna process, it is necessary to ensure equal access to knowledge in the regions.

From the point of view of the authors, considerable attention should be paid to preparedness of the trainees to the very process of learning.

People in the regions are not always ready to stand constant strain during learning. The rigidity of thinking and inability to use knowledge in different contexts is frequently observed.

The very crucial aspect which was noted during the work in the regions was strong influence of the human factor. People in the regions rely on the opinion of their neighbours or acquaintances much more willingly than on the opinion of experts or trainers.

Due to lack of information, adults in the regions often do not know about the existence of new trends in the management science, frequently do not know how to connect theory to practice, and cannot trace logical connections between formal requirements for learning and implementation of such learning in practice.

It is possible that during implementation of training in the regions it is necessary to approach the needs of trainees living in the regions more flexibly, discover their needs and plan instruction being oriented on the possibility of applying the acquired knowledge in practice.

\section{Conclusions and Proposals}

In the regions, instruction should involve wider strata of society. Such instruction allows broadening one's outlook, determine the directions in which new information should be searched for and organize the knowledge management system. For the information taught by outside trainers to be perceived, it is neces- 
sary to prepare thoroughly and think through everything down to the smallest detail. In terms of teaching in the regions, the human factor becomes especially important. The ability of a trainer to establish contact with the trainees has a direct effect on the result of learning. In the regions, knowledge management can be spoken about not as the system inside an organization, but as acquisition, mastering, renewal and exchange of knowledge between separate economies, adjacent farms, and acquaintances. Such formations appear according to the rule of geographical distribution, and in this case it seems appropriate to recall clusters described by Porter (Porter, 2000). But in this context, similar clusters not only protect their own interests, but also prevent new external information from being disseminated. Absence of information about everything new in the field of management or knowledge management does not contribute to shaping of demand for search for such information and, thus, impedes regional development.

Organizing training at the high level and involving experienced trainers as well as serious attitude to preparation of handouts can change the attitude in the regions to the process of learning and create culture oriented towards the exchange of knowledge.

Of considerable importance is the experience of a trainer who can not only explain the theoretical bases of his/her subject, such as project management, management or marketing, but who, on the examples clear to the trainees, can show the practical value of these theories.

Qualitative on-site training can change in the regions the long-standing vision of learning as something book-learned having no practical benefit.

Planning such instruction, it is necessary to take into consideration that the level of educational attainment of people in groups will be completely different. Also, the fact that people are not accustomed to studying for a long time and are not able to perceive a lot of information at a time should be taken into consideration.

This work has been supported by the European Social Fund within the project "Support for Doctoral Studies at University of Latvia".

\section{References}

Porter, M. (2000). Location, Competition, and Economic Development: Local Clusters in a Global Economy. Economic Development Quarterly, Vol. 14, No. 1, February, p. 15-34.

Drucker, P. F. (1999). Management Challenges for the 21st Century. Harper Business, p. 207.

Corredoira, R. A., Rosenkopf, L. (2010). Should Auld Acquaintance Be Forgot? The Reverse Transfer of Knowledge through Mobility Ties. Strategic Management Journal, Vol. 31, No. 2, p. 159-181.

The Lisbon Council. EU 2020: Why Skills are Key for Europe's Future By Paul Hofheinz. (2009). Website: http://www. lisboncouncil.net/initiatives/human-capital.html [skat. janv. 2012].

Oertenblad, A. (2001). On differences between organizational learning and learning organization. Learning Organization MCB University Press, Vol. 8, No. 3, p. 125-133.

Argote, L., Ingram, P. (2000). Knowledge transfer: A Basis for Competitive Advantage in Firms. Organizational Behavior and Human Decision Processes, Vol. 82, No. 1, p. 150-169.

Harrington, H. J., Voehl, F. (2008). Knowledge Management Excellence. The Art of Excelling in Knowledge Management, p. 269.

Joy-Matthews, J., Megginson, D., Surtees, M. (2004). Human resource development. 3-rd ed. London: Kogan Page, p. 565.

Uhlaner, L., Van Stel, A., Meijaard, J., Folkeringa, M. (2007). The relationship between knowledge management, innovation and firm performance: evidence from Dutch SMEs.

Lundvall, B. A., Tomlinson, M. (2001). Learning by comparing: reflection on use and abuse of benchmarking. In: G. Sweeney (ed.). Innovation, Economic Progress and Quality of Life. London: Edward Elgar.

Blackler, F. (1995). Knowledge, Knowledge Work and Organizations: An Overview and Interpretation. Organization Studies, No. 6, p. 1021-1046. 


\section{ŽINIŲ VALDYMO SISTEMOS SUAUGUSIUUŲ MOKYMO PROCESE TOBULINIMAS, SIEKIANT EFEKTYVIOS REGIONU PLETROS}

INESSA VORONTCHUK, IRINA LANDO

Latvijos universitetas (Latvija)

\section{Santrauka}

Pirmą kartą žmonijos istorijoje išgyvename situaciją, kai dèl labai išaugusio informacijos kiekio žmonès nebesugeba jos apdoroti, be to, nebesugeba paversti šios informacijos žiniomis. Ne visa informacija yra vertinga, faktų kaupimas ne visada yra žinios. Norėdami nepasimesti informacijos sraute, turime gauti naujų žinių ir igyti igūdžių, t. y. kompetencijų, kurios padètų susivokti informacijos sraute ir išvengti informacinès perkrovos.

Panaši problema kyla ir darbuotojams jų darbo vietose dẻl greitai senstančios ịangos. Nors kompiuteriai atrodè didžiausias techninès minties laimejjimas, jie sensta neissivaizduojamai greitai. Kas dar neseniai atrodè kaip naujas techninis sprendimas, tampa standartiniu vos per šešis mėnesius, o po trejų metų jau nebelaikomas moderniu. Ką daryti su pasenusiais kompiuteriais ar kita ịranga, kuri nebepajègi apdoroti darbui būtino informacijos kiekio? Pirmiausia būtina ją atnaujinti, vèliau paprasčiausiai pakeisti. Bet ką daryti, jei žmogus, kuris yra svarbiausias žinių kūrimo, perdavimo ir atnaujinimo veiksnys, nebegali susidoroti su šia užduotimi? Senėjančios Europos kontekste, ilgèjant pensiniam amžiui, ši problema vis aktualèja, nes pokyčiai verčia žmones prisitaikyti nepaisant jų amžiaus.

Siekiant išspręsti šią problemą, autoriai siūlo mokymo sistemą žmonèms, kurie nori padidinti informacijos apdorojimo greiti. Pavyzdžiui, greito issiminimo ugdymas, greitasis skaitymas ir teksto formavimas leidžia greičiau prisitaikyti prie kintančios aplinkos reikalavimų ir sparčiau apdoroti dideli informacijos kieki. Tai ypač svarbu regionų vystymuisi, kur žmonès dažnai gauna jau pasenusią informaciją, todèl būtina užtikrinti lygiu galimybiu principo taikymą regionų ir miestų gyventojams.

PAGRINDINIAI ŽODŽIAI: suaugusiuju mokymas, žiniu valdymas, regionu vystymasis. 